\title{
Luis Artigue, Tres, dos, uno... jazz, Valladolid, Fundación Jorge Guillén, 2007, 74 pp.
}

Como muchos otros poetas, Luis Artigue reivindica la poesía como ámbito de libertad: libertad métrica, variabilidad en el desarrollo, expansión emotiva e imaginativa... Es lo que encontramos en Tres, dos, uno... jazz (2007), que fue premio de la Academia Castellano-Leonesa de Poesía para jóvenes creadores.

El sujeto de estos poemas, reflejo autobiográfico del poeta, es un personaje enfermo y hospitalizado, con "la inminencia de la muerte, / el miedo, / la tranquilidad en blanco del hospital a oscuras". Y en esos momentos de largas noches hospitalarias, la radio le sirve al enfermo para apaciguar sus pensamientos negativos y de acompañamiento en la blanca soledad: "el jazz era una forma de estar acompañado", escribe el poeta, y de cultivar cierta nostalgia, recuerdos, evocaciones y deseos; era un modo también de encender la imaginación, de viajar y rememorar el ámbito del jazz, club, cines, músicos y coristas: "Aún hay jazz, hay imaginación, hay ríos navegables / en barcos de vapor, hay fe y memoria anímica...". El jazz devuelve al mundo a ese personaje que lucha contra la enfermedad y la miseria física, crea un clima vital de esperanza, porque la música hace concebir mundos donde anida la tragedia y el amor, la vida, en suma.

Esta situación es la que da al poemario un sentido de intimidad. Es una poesía intimista porque el personaje poético expresa sus vivencias interiores, las que el jazz suscita en su soledad existencial. En distintas ocasiones, los versos nos hablan de estas vivencias íntimas en que desemboca la imaginación; y el propio poeta ha aludido al "intimismo contagioso" del poemario, entendido como "testimonio de un convaleciente hospitalario que se encomienda a la música para hacernos saber así que todo origen tiene algo de destino"; son palabras que aparecen en la página última, donde se refiere también a algo que adivina pronto el lector: que en las distintas fantasmagorías presentes en el poemario ha colaborado decisivamente el cine negro: "El autor nos introduce en un mundo como de cine negro con clubs, coristas de cuerpo justiciero, matones con cara de acertijo, camareras licenciosas que llevan su corazón en la mano, viejos discos-fetiche, drogas y disturbios emocionales, sí, la vida, la dicha, el suelo, el cielo, el ritmo, el jazz".

El jazz como reconocimiento en el dolor, en la amistad, en el amor. El jazz como recuerdo y evocación, encuentro y refugio en el dolor y el miedo, atmósfera de lo súbito, de lo inesperado, de la creación improvisada que remoje los humores del cuerpo y del alma y que hace asomarse a otros mundos por la imaginación o la fantasía y trazar algún rasgo de esperanza.

El jazz suscita múltiples sugerencias. Algún poema, como el titulado "Harto de la fortuna del dolor...", se desarrolla como expresión todo él de las imágenes que provoca la música del jazz, en este caso concreto, la trompeta de Miles Davis.

En cualquier caso, el poemario explicita el amor al jazz, a las vidas que rodaron en torno al mismo, a sus músicos, a la moral del jazz y a lo que él representaba como modo de dar voz a lo oculto psicológica y socialmente, de 
libertad y de rebeldía, en suma. De ahí que sintamos en estos versos el ritmo del jazz, pero no como melodía acogedora, sino como vigor, energía, liberación e improvisación luminosa, como la vida misma. Hay un antecedente inevitable: el Blues castellano de Gamoneda; pero los poemas de Artigue respiran otro aire y otro ritmo. Si uno conoce la literatura de Luis Artigue no se extrañará de su entrañamiento con la atmósfera del jazz como "música sin preceptos", como de igual manera le atraen los seres ocasionales que un día aparecen en la ciudad como espejo de la débil frontera que separa el lujo y la miseria o, simplemente, las distintas maneras de enfocar la vida; hablo del mendigo, el acordeonista de la calle Ancha $\mathrm{u}$ otros personajes al margen de lo comúnmente establecido y que acaban formando parte del paisaje urbano o del recuerdo y la imaginación; seres que viven la vida de forma no reglada, que desprecian lo convencional y expresan así su rebeldía, los seres de la noche, "cuando los héroes y los mendigos beben juntos" al calor de lo inesperado; seres en el desamparo de su locura, como la mujer indigente del poema "Esa mujer se ha convertido sin desearlo en una estatua...", a la que se imagina hermosa antes de que el rayo de la locura quemara su mente y que es el reverso de todos, pues a todos "les recuerda sin ambages / que están aquí y muy próximos el cielo y el infierno"; los seres rebeldes que, finalmente, son reconducidos con camisas de fuerza "para que todo siga como siempre", como expresa el verso último del libro.

Tres, dos, uno... jazz es, además, una indagación en la música afronorteamericana que había nacido a comienzos del siglo $\mathrm{XX}$ en el sur de los Estados Unidos, una indagación desde sus raíces a las modalidades que fueron surgiendo con el paso de los años. En realidad el libro nos propone un concierto que introduce Louis Armstrong, que destacó pronto como uno de los mejores músicos de Nueva Orleáns, verdadera cuna del jazz, y después como cantante y director de orquesta; es Armstrong el que anuncia el concierto: "Buenas noches señoras y señores: hemos venido de lejos pero ahora vamos a tocar alguna de las buenas para ustedes"; y es Duke Ellington, estrella del Cotton club de Harlem, quien despide el concierto: "Muchas gracias señoras y señores. Antes de irnos los chicos de la orquesta me han pedido que les diga que los queremos locamente". Y entre la entrada y la despedida se van sucediendo las distintas innovaciones que el jazz fue padeciendo, de los orígenes en la confluencia del "ragtime sincopado" de Nueva Orleáns y "el descarnado blues del delta del Mississippi" (primera parte) al swing de los clubes de Chicago y Kansas City en los años treinta y al big bands de la segunda guerra mundial (segunda parte), pasando por "los laberintos armónicos del be bop" de los años cuarenta (recuérdese el nombre, entre otros, de Charlie Parker) (tercera parte) y el cool bop, nacido a fines de la misma década (cuarta parte), el hard bop o funky de mediados de los cincuenta, que quiso volver a las raíces negras del jazz, el blues y el gospel song (quinta parte), y, finalmente, el free jazz o new thing, que surgió a mediados de los sesenta, convulso y desenfrenado, fruto de la improvisación colectiva (sexta parte). La evolución del jazz, y los nombres de sus creadores, intérpretes y renovadores que van salpicando los poemas puede seguirse en cualquier enciclopedia, pero el poeta, tal vez temiendo la ignorancia del lector, o acaso como información y guía de lectura, y con el fin de crear previamente la 
atmósfera sentimental apropiada, se ve obligado a alargar considerablemente los títulos aclaratorios de cada parte y de cada poema; he aquí uno de cada: el de la sexta parte nos ofrece el clima del free jazz ("ropa sudada") y su carácter caótico, impulsivo y violento: "Entre esa mampostería de la ropa sudada el militante efusivo e histérico free jazz al integrar incluso las disonancias nos introduce en un territorio sonoro cercano al ruido como argumentando que la intensidad es el idioma de la plenitud" (en mayúsculas en el original); un poema de la segunda parte lleva este título: "Otro hospital psiquiátrico para cuerdos llamado cotton club donde hasta lo improvisado parece calculado" (mayúsculas en el original, como todos los títulos). No todos los títulos son tan referenciales, pues el poeta acumula en ellos distintas funciones propias del título en general, informativas, conativas, poéticas o de cualquier otro tipo, pero siempre como necesario factor de legibilidad, pues el título funciona como puerta de entrada en el texto y se convierte en la primera guía de información y descodificación del mismo; el siguiente título de un poema de la cuarta parte es de carácter poético, pero, a la vez expresa una experiencia vital intensa: "Tras los encontronazos en las encrucijadas todos nos convertimos en un hombre tan viejo que sólo puede ya soñar con sus recuerdos". La relación del título y el poema sería otro capítulo explicativo enjundioso y nada breve. Y dejo para los interesados la relación entre los diferentes ritmos, estilos y modulaciones del jazz con los ritmos y la tonalidad sentimental de los poemas de cada parte.

El desarrollo del poema es otro aspecto de interés. En determinados poetas, el primer verso está cuajado como una perla y es como un golpe de aldaba para el lector. Él verso de inicio parece resumir un mundo, como un precipitado químico que ha resultado de reacciones íntimas previas (por ejemplo: "Me he sentado en el centro del bosque a respirar" verso con que Colinas inicia uno de los poemas de Noche más allá de la noche); no es así de ordinario en los poemas de Artigue, que suelen comenzar con versos de talante narrativo para ir contrapunteando el poema con ritmos rápidos y pausados, desarrollos más o menos extensos con versos fulgurantes o afilados como estiletes, creando huecos entre los versos o escalonándolos para que se vea el poema como un cuerpo material también que alterna ritmos y parece ofrecer una guía de lectura tanto rítmica como semántica; y de igual manera, en el poema se suceden fragmentos narrativos, reflexivos, evocadores para terminar, generalmente, con un golpe de efecto que no cierra emocionalmente el poema, sino que lo deja vibrando, resonando. Valga como ejemplo el poema titulado "Otro hospital psiquiátrico para cuerdos...", de la segunda parte, en el que se van alternado la situación real del sujeto y su estado anímico, con la oreja pegada a su radio de galena para escuchar la música de Duke Ellington y fantasear con el ambiente del cotton club en el que aquel desarrolló con éxito su nuevo estilo, para finalizar el poema con dos versos que resumen los dos motivos, la situación del sujeto y la música con la que viajó a Nueva Orleáns sin moverse de la cama: "Algo deberé siempre al músico entusiasta / que compone mi sueño; nuestros sueños".

Es así como Luis Artigue ha construido un libro brillante y original formal y temáticamente, cuajado de diferentes ritmos al son del jazz escuchado, 
memorizado y evocado cuando ya la vida ofrecía otras esperanzas por encima de los tejados hospitalarios del protagonista en primera persona del poemario, el que lleva la voz cantante diríamos para no salirnos de los motivos musicales o jazzísticos de esta poesía.

José Enrique Martínez 